\title{
DETERMINATION OF YIELD AND QUALITY PARAMETERS OF OIL SUNFLOWER GENOTYPES GROWN IN TURKEY
}

\author{
Volkan $G U L^{1 *}$, Furkan COBAN ${ }^{2}$ \\ ${ }^{1}$ Bayburt University, Faculty of Applied Sciences, Organic Farming Management, Bayburt, TURKEY \\ ${ }^{2}$ Ataturk University, Agriculture Faculty, Field Crop Departments, Erzurum, TURKEY \\ ${ }^{*}$ Corresponding author:volkangul555@gmail.com
}

Received: 10.09 .2019

\begin{abstract}
Sunflower (Helianthus annuus $\mathrm{L}$ ) has gained importance in the world as a significant oilseed for vegetable oil. The reactions of the same sunflower genotypes to varying ecologies are different, and yield and yield characteristics may vary depending on this. In this study, we were interested in understanding the differential sensitivity of specific sunflower genotypes to different agro-ecological environments in Turkey. A 2-year (2015-2016) study was conducted on a clay-loam soil in a low and high altitude environment to (i) evaluate the genotype $\times$ location $\times$ year interaction $(G \times L \times Y)$ for sunflower genotypes, (ii) predict yield components performance and identify high stable sunflower genotypes, and (iii) make genotype-specific management and high performing genotype recommendations within and across agro-ecological regions. The highest yield of seed and oil yield was obtained from the Coral $\left(G_{1}\right)$ genotypes, averaging 3558.5 and $1535.6 \mathrm{~kg} \mathrm{ha}^{-1}$, respectively in Erzurum and from the $64 \mathrm{LC108}\left(\mathrm{G}_{4}\right)$ genotypes averaging 2905.7 and $1267.4 \mathrm{~kg} \mathrm{ha}^{-1}$, respectively in Samsun ecological conditions. As a result, the determination of the sunflower genotypes suitable for the region will provide the opportunity to obtain high-yield and high quality products because the soil, environment and climatic factors of the region in which they are grown are very useful in determining seed yield and oil content.
\end{abstract}

Keywords: Environment, genotypes, Helianthus annuus L, oil content, seed yield

\section{INTRODUCTION}

Worldwide sunflower production is approximately 47 million tons and covers a total area of 26.5 million hectares. The main producers are Ukraina, 25.5\%; Russia, $21.3 \%$; Argentina, $7.5 \%$ (Faostat, 2017). Sunflower takes an important place in terms of raw materials provided for the oil industry and of added value, as well as bring-in income for producers in Turkey's economy.

Sunflower is very substantial all over the world due to its utilities as oil, food, forage and demand of the enormous population. In Turkey, $46 \%$ of vegetable oil needs are obtained from sunflower. Sunflower oil is colourless, odourless, resistant to oxidative changes during storage, cooking, and because of its high edible oil quality is preferred by the majority of the population in our country. The main reasons why production is so high compared to other oil crops is the fact that the main adaptability is extensive and very suitable for mechanization, insensitive in photoperiod (Goyne and Hummer, 1982), tolerance to drought, cold, all growing well in soil types and adapt to different ecologies (Alberio et al., 2015).
Despite the high adaptability of sunflowers, the reactions of the same genotypes to varying ecologies are different and yield and yield characteristics may vary depending on this (Schneiter and Miller, 1981). All of oilseed sunflower genotypes that are grown in Turkey close to the hybrid genotypes. Since the stability of hybrid sunflower genotypes is higher than non-hybrid varieties, genotype $\mathrm{x}$ environment interactions of these genotypes are lower and therefore stable high yields can be obtained. Thus, more production can be made by increasing the yield obtained from the unit area in the sunflower. Furthermore, when the relative yield of the sunflower genotypes grown in the different environment ecologies are highly significant, genotype $\mathrm{x}$ environment interactions have a main challenging factor and is within possibility helpful for breeding sunflower in specific geographical areas.

In this study, we were interested in understanding the differential sensitivity of specific sunflower genotypes to different agro-ecological environments in Turkey. The objectives of the study were as follows: (i) to evaluate the genotype $\times$ location $\times$ year interaction $(\mathrm{G} \times \mathrm{L} \times \mathrm{Y})$ for sunflower genotypes, (ii) to predict yield components performance and identify high stable sunflower genotypes, 
and (iii) to make genotype-specific management and high performing genotype recommendations within and across agro-ecological regions.

\section{MATERIALS AND METHODS}

\section{Site description}

Field experiments were conducted at Kavak district in Samsun $\left(\mathrm{L}_{1}\right)$, (N 4104'39.2" E 3602'41.6", $636 \mathrm{~m}$ above sea level) and at Ataturk University Agricultural Research Center in Erzurum ( $\left.\mathrm{L}_{2}\right)$, (N 39 55'59.9" E 41 ${ }^{\circ} 14^{\prime} 10.6^{\prime \prime}$, and $1787 \mathrm{~m}$ above sea level) from 2015 and 2016 growing season. Locations were chosen to represent high and lower altitudes regions in Turkey. The soils of the experimental plots at two sites, $\mathrm{L}_{1}$ and $\mathrm{L}_{2}$, were clay loam, which consists of deep, moderately well-drained soils formed from less material, with approximately $2.42\left(\mathrm{~L}_{1}\right), 1.66 \%$ $\left(\mathrm{L}_{2}\right)$ organic matter. Before planting in each year, composite soil samples were taken at 0 to $30 \mathrm{~cm}$ depth from all sites, according to the method reported by Klute and Dinauer (1986) and Page et al. (1982). The 0-30 cm soil layers contained respectively $153.1 \mathrm{~kg} \mathrm{ha}^{-1}\left(\mathrm{~L}_{1}\right)$, $103.15 \mathrm{~kg} \mathrm{ha}^{-1}\left(\mathrm{~L}_{2}\right)$ available $\mathrm{P}$ (Olsen and Sommers, $1982)$ and $915.5 \mathrm{~kg} \mathrm{ha}^{-1}\left(\mathrm{~L}_{1}\right), 1454.1 \mathrm{~kg} \mathrm{ha}^{-1}\left(\mathrm{~L}_{2}\right)$ available $\mathrm{K}$ (Rhoades, 1982) and also the soil of the study locations were neutral ( $\mathrm{pH}$ 7.13-7.73). The two experimental locations $\mathrm{L}_{1}$ is located dry sub-humid regions and $\mathrm{L}_{2}$ is located in the semiarid regions, with long-term annual average precipitation amounts of 716.6 and $431.2 \mathrm{~mm}$, respectively. Also, results of chemical composition on soil, climate conditions, coordinate sowing, and harvest date over the two years for each location are indicated in Table 1 and Figure 1.

Table 1. Site description during sunflower growth in two growing seasons (2015 and 2016) at Samsun ( $\left.\mathrm{L}_{1}\right)$; and at Erzurum $\left(\mathrm{L}_{2}\right)$.

\begin{tabular}{|c|c|c|c|c|}
\hline Site description & \multicolumn{2}{|c|}{ Samsun (L1) } & \multicolumn{2}{|c|}{ Erzurum (L2) } \\
\hline Coordinates & \multicolumn{2}{|c|}{$\mathrm{N} 41^{\circ} 04^{\prime} 39.2^{\prime \prime}$ E $36^{\circ} 02^{\prime} 41.6^{\prime \prime}$} & \multicolumn{2}{|c|}{$\mathrm{N} 39^{\circ} 55^{\prime} 59.9^{\prime \prime}$ E $41^{\circ} 14^{\prime} 10.6^{\prime \prime}$} \\
\hline Altitude (m) & & 36 & & \\
\hline \multirow[t]{2}{*}{ Soil texture } & \multicolumn{2}{|c|}{ Clay-loam } & \multicolumn{2}{|c|}{ Clay-loam } \\
\hline & 2015 & 2016 & 2015 & 2016 \\
\hline Soil pH (0-30 cm depth) & 7.13 & 7.52 & 7,73 & 7,20 \\
\hline $\mathrm{CaCO}_{3}(\%)$ & 17.7 & 17.7 & 0,68 & 1,29 \\
\hline Organic matter (\%) & 2.38 & 2.46 & 2,28 & 1,04 \\
\hline $\mathrm{P}_{2} \mathrm{O}_{5}(\mathrm{~kg} / \mathrm{ha})$ & 150.3 & 155.9 & 119.3 & 87.0 \\
\hline $\mathrm{K}_{2} \mathrm{O}(\mathrm{kg} / \mathrm{ha})$ & 870.0 & 961.0 & 1548,1 & 1360,4 \\
\hline Annual precipitation. $\mathrm{mm}$ & 785.2 & 918.1 & 587.5 & 441.2 \\
\hline Average maximum temperature. ${ }^{\circ} \mathrm{C}$ & 19.02 & 19.49 & 13.6 & 12.8 \\
\hline Average minimum temperature. ${ }^{\circ} \mathrm{C}$ & 12.43 & 12.34 & -1.1 & -1.3 \\
\hline Average temperature ${ }^{\circ} \mathrm{C}$ & 15.50 & 15.66 & 6.1 & 5.5 \\
\hline Sowing Date & 29 Apr. & 16 Apr. & 20 May & 06 May \\
\hline Harvest Date & 04-11 Sep. & 23 Aug.-3 Sep. & 17-30 Sep. & 12-23 Sep. \\
\hline Total Day & $128-135$ & $129-140$ & $120-133$ & $128-139$ \\
\hline
\end{tabular}

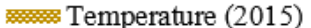

- Precipitation (2015)

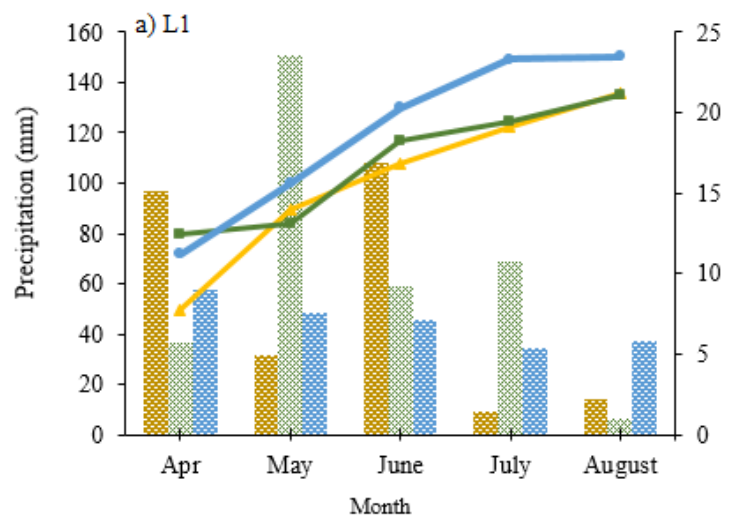

팠ㅆㅆ Temperature (25 year)

Precipitation (25 year)

Figure. 1. Monthly mean temperature and total monthly precipitation during sunflower growth in two growing seasons (2015 and 2016) at (a) Samsun $\left(\mathrm{L}_{1}\right)$; and at (b) Erzurum $\left(\mathrm{L}_{2}\right)$. Note: Line graph showing precipitation and bar graph showing temperature 


\section{Germplasm}

Ten genotypes (Coral, 63F73, 64LL05, 64LC108, Goldsun, Sems, AGA-1301, Duna, Bosfora and 64G46) were chosen to represent small vs large fruit, disease resistant vs susceptible, and hybrid type (Table 2). Its germination rate was tested under controlled conditions before the study and found to be $>94 \%$.

\section{Study design and plot management}

A Randomised Complete Block Design, with three replicates, was used for the trial. Each plot of sunflower genotype consisted of four $4 \mathrm{~m}$-long rows, $70 \mathrm{~cm}$ apart, and plants of the same genotypes were spaced at $0.25 \mathrm{~m}$ within each row per plot and per replicate. The plots were spaced $1 \mathrm{~m}$ apart. Before seeding, basal fertilization (100 $\mathrm{kg} \mathrm{N} \mathrm{ha-1,} 80 \mathrm{~kg} \mathrm{P} 2 \mathrm{O} 5 \mathrm{ha}^{-1}$,) was incorporated into the soil. Nitrogen and phosphorus were broadcast applied as ammonium sulfate and triple superphosphate, respectively, and incorporated into the seedbed before sowing. Weeds were controlled by hand-hoeing during the growth period. All plots were furrow irrigated regularly to avoid drought stress. Plots were irrigated three times (seeding, flowering and seed development stage) in $\mathrm{L}_{1}$ and four times (seeding, flowering and two times seed development stage) in $\mathrm{L}_{2}$ during both study years. Each irrigation brought the soil moisture back to near field capacity.

Table 2. The 10 sunflower genotypes general characteristics description

\begin{tabular}{|c|c|c|}
\hline Code & Genotype & Description \\
\hline G1 & CORAL & $\begin{array}{l}\text { Early variety, high yield potential, high tolerance to stress conditions, can be grown in all kinds } \\
\text { of soils, sunflower head structure is oblique and convex features. }\end{array}$ \\
\hline $\mathrm{G} 2$ & $63 \mathrm{~F} 73$ & $\begin{array}{l}\text { Early variety, high yield potential, high tolerance to stress conditions, can be grown in all kinds } \\
\text { of soils, sunflower head structure is oblique and convex features. }\end{array}$ \\
\hline G3 & 64LL05 & $\begin{array}{l}\text { Medium early variety, high tolerance to stress conditions, high yield, can grow in all kinds of soil } \\
\text { structure, sunflower head structure is oblique and convex features. }\end{array}$ \\
\hline G4 & 64LC108 & $\begin{array}{l}\text { Medium early variety, high tolerance to stress conditions, high yield, can grow in all kinds of soil } \\
\text { structure, sunflower head structure is oblique and convex features }\end{array}$ \\
\hline G5 & GOLDSUN & $\begin{array}{l}\text { Early variety, medium height, resistant to flexure and drought, high yielding and has an oblique } \\
\text { feature of sunflower head structure. }\end{array}$ \\
\hline G6 & SEMS & $\begin{array}{l}\text { Very early variety, yield and adaptable highly, drought-resistant, sunflower head structure is } \\
\text { slightly tilted and concave features }\end{array}$ \\
\hline G7 & AGA-1301 & $\begin{array}{l}\text { Medium early variety, high yield, resistant to stress conditions, sunflower head structure is semi- } \\
\text { inclined feature. }\end{array}$ \\
\hline G8 & DUNA & $\begin{array}{l}\text { Early variety, high yield, resistant to drought and environmental conditions, sunflower head } \\
\text { structure is slightly downward oblique and convex features. }\end{array}$ \\
\hline G9 & BOSFORA & $\begin{array}{l}\text { Early variety, high tolerance to stress conditions, high yield, can grow in all kinds of soil } \\
\text { structure, sunflower head structure is oblique and concave features }\end{array}$ \\
\hline G10 & 64G46 & $\begin{array}{l}\text { Medium early variety, high tolerance to stress conditions, high yield, can grow in all kinds of soil } \\
\text { structure, sunflower head structure is oblique and convex features. }\end{array}$ \\
\hline
\end{tabular}

\section{Data collection and statistical analysis}

The agro-morphological characteristics of plant height, stem and head diameter, 1000-seed weight, the ratio of dehulled/hulled seed weight were measured based on each replicate performance, according to the method reported by Ozer et al. (2004). Fifteen plants were collected randomly from the central two rows and the following growth and yield component variables were recorded for each plot. At harvest, seed yield was calculated in the four center rows of each experimental unit, and $0.5 \mathrm{~m}$ of plants were discarded from the end of the rows. Seeds were separated from the head by hand threshing. The seed yield was corrected to $10 \%$ moisture. Seed yields per plant were weighed using an electric weighing balance. Seed yield was measured in gram per plot and converted to kilogram (kg) per hectare (ha). The yield was recorded in three replicates over two years and at two localities. A $3 \mathrm{~g}$ subsample of seed for each treatment replicate was used for determining seed oil content by Soxhlet apparatus (Andrich et al., 2001). Oil yield was then converted and expressed in $\mathrm{kg} / \mathrm{ha}$ as the product of seed yield and percentage oil contents. The experiment was randomly designed with three replications. Data were subjected to analysis of variance (Anova) and means were separated by Duncan multiple range test at $\mathrm{p}<0.01$ significant level.

\section{RESULTS AND DISCUSSION}

\section{Plant height}

Average plant heights of sunflower genotypes grown under different location and their variance analyses were given Table 3. Year, location, and genotype factors nor the year $\mathrm{x}$ location, year $\mathrm{x}$ genotype, location $\mathrm{x}$ genotype, and year $\mathrm{x}$ location $\mathrm{x}$ genotype interactions were not significant of sunflower genotypes grown in different locations.

According to the 2015 data obtained from the experiment at $\mathrm{L}_{1}$, the highest plant lengths were obtained from the $G_{9}, G_{1}$, and $G_{4}$ genotypes, which were 127.60, 127.40 , and $126.11 \mathrm{~cm}$, respectively, while the lowest plant heights were obtained from the $\mathrm{G}_{5}$ and $\mathrm{G}_{3}$ genotypes, which were 96.40 and $99.46 \mathrm{~cm}$, respectively. 
At $\mathrm{L}_{2}$, the $\mathrm{G}_{1}(142.96 \mathrm{~cm})$ and $\mathrm{G}_{9}(131.16 \mathrm{~cm})$ locations produced the highest plant heights, and the $\mathrm{G}_{3}$ (107.10 $\mathrm{cm})$ genotype gave the lowest value. The plant lengths obtained from $\mathrm{L}_{2}$ were higher than those from $\mathrm{L}_{1}$ according to the genotypes. Although the $\mathrm{G}_{1}$ and $\mathrm{G}_{9}$ genotypes showed different results at different locations, it was observed that these genotypes gave the highest values at both locations. The plant heights at $\mathrm{L}_{1}$ varied between $114.66-153.50 \mathrm{~cm}$, and the plant heights at $\mathrm{L}_{2}$ varied between 100.33 and $132.80 \mathrm{~cm}$. The highest plant heights obtained from $L_{1}$ and $L_{2}$ were from the $G_{6}(153.50 \mathrm{~cm})$ and $\mathrm{G}_{1}(132.80 \mathrm{~cm})$ genotypes, respectively.

Table 3. Plant height, stem diameter averages and variance analysis results of sunflower genotypes grown in different regions

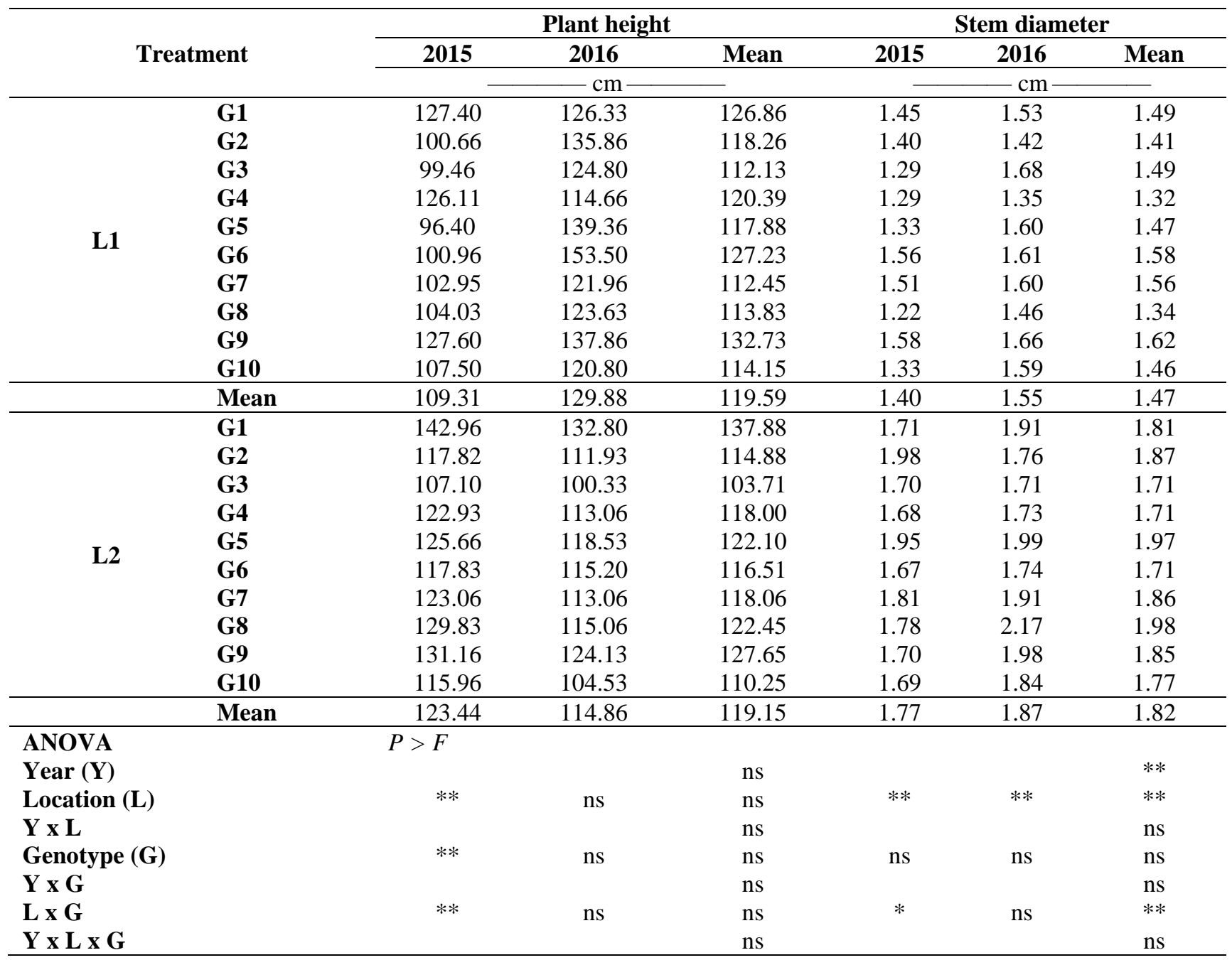

*Denotes significance difference at $\mathrm{p} \leq 0.05 . * *$ Denotes significance difference at $\mathrm{p} \leq 0.01$, respectively, ns, non-significant difference.

Previously recorded average plant height values of the genotypes at different locations are $134.16-181.70 \mathrm{~cm}$ (Killi and Tekeli, 2016), 126-207 cm (Alem et al., 2016) and 142-176 cm (Tozlu et al., 2008). The results obtained by those researchers were higher than our results.

We observed changes in plant height due to the genetic differences between the genotypes and environmental conditions at different locations (Adugna and Labuschagne, 2003; Mostafa and Ashmawy, 1998; Alem et al., 2016).

\section{Stem diameter}

According to the results of the statistical analysis of different sunflower genotypes obtained stem diameter average values (Table 3 ) year, location and location $\mathrm{x}$ genotype interactions at the level of $1 \%$, while year $\mathrm{x}$ location, year x genotype, and year x location $\mathrm{x}$ genotype interaction statistical results are insignificant was observed.

The highest stem diameter value $(1.68 \mathrm{~cm})$ was obtained from the $\mathrm{G}_{3}$ genotype in 2016, while the lowest stem diameter value $(1.22 \mathrm{~cm})$ was obtained from the $\mathrm{G}_{8}$ genotype in 2015 at $\mathrm{L}_{1}$. At $\mathrm{L}_{2}$, the highest steam diameter value $(2.17 \mathrm{~cm})$ was obtained from the $\mathrm{G}_{8}$ genotype in 2016, while the lowest stem diameter value $(1.67 \mathrm{~cm})$ was obtained from the $\mathrm{G}_{6}$ genotype in 2015 . In 2016, the stem diameter values obtained at locations I and II were higher than those in 2015. In their study to determine the characteristics of different sunflower genotypes, Iqbal et al. (2018) reported the diameter of the stem to be 1.28$1.66 \mathrm{~cm}$. This result is similar to our results. The change in stem diameter varies depending on genetic, climatic, 
and environmental factors and cultivation techniques (e.g., irrigation, hoeing) (Arioglu, 2007; Habibullah et al., 2007).

\section{Head Diameter}

Table 4 shows the average values and variance analysis results of the table diameter values of the sunflower genotypes grown in different locations. Year, location, genotype, and year $\mathrm{x}$ genotype interaction were statistically significant $(\mathrm{p}<0.01)$ according to the head diameter values of the sunflower genotypes. In contrast, the year $\mathrm{x}$ genotype, location $\mathrm{x}$ genotype, and year $\mathrm{x}$ location $\mathrm{x}$ genotype interactions were not statistically significant.

Head diameters were 19.86 and $20.08 \mathrm{~cm}$ in 2015 and 2016, respectively (Table 4). The head diameter values obtained from different locations and years yield the same results as the average values of the oil sunflower genotypes. Some differences may occur depending on the genetic structure of the genotypes and environmental differences. The most considerable head diameter value $(22.03 \mathrm{~cm})$ was obtained from 2015 at $\mathrm{L}_{2}$, while the lowest head diameter value $(14.43 \mathrm{~cm})$ was obtained from 2015 at $\mathrm{L}_{1}$.

Table 4. Head diameter, 1000 Seed Weight averages and variance analysis results of sunflower genotypes grown in different regions

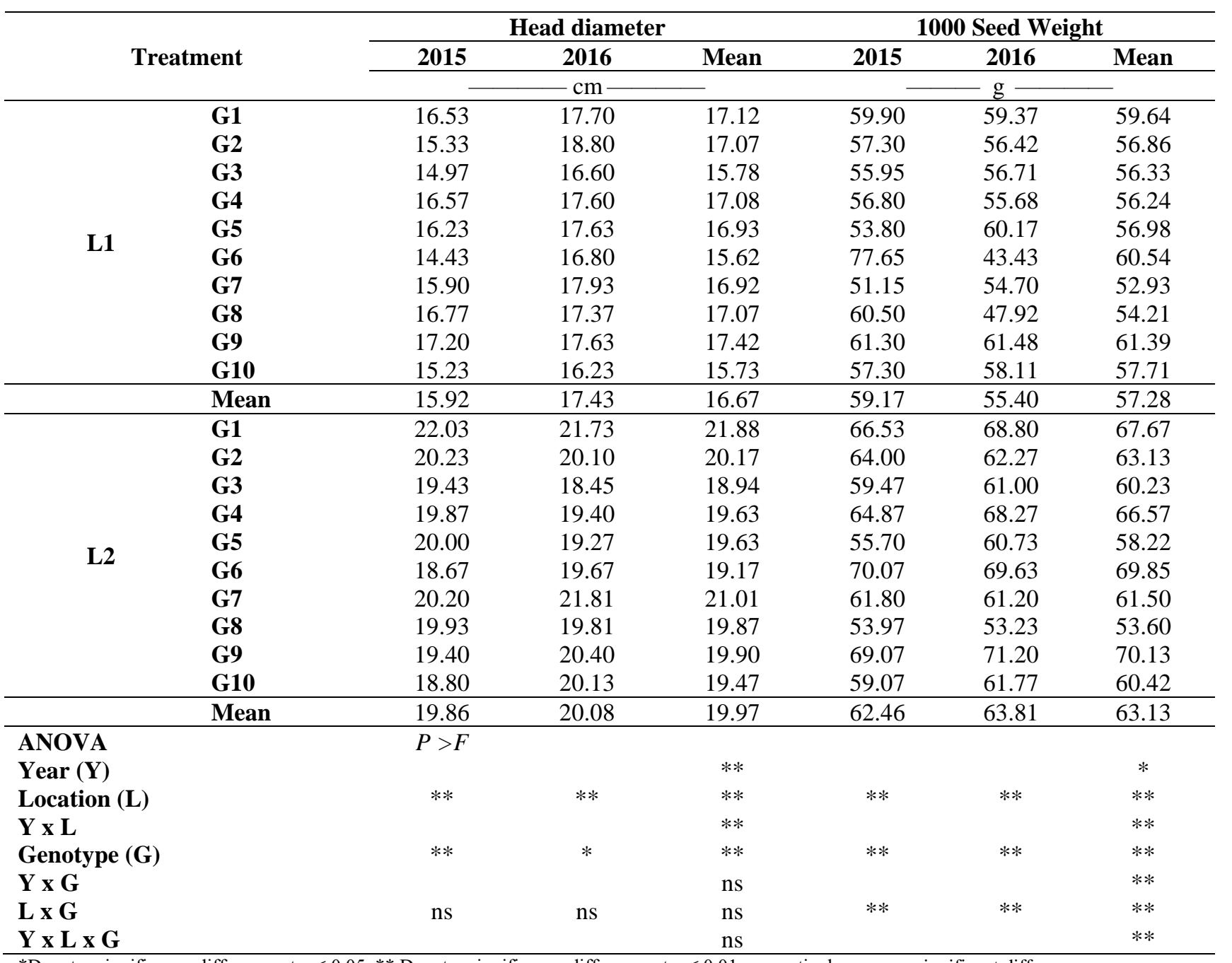

*Denotes significance difference at $\mathrm{p} \leq 0.05 .{ }^{* *}$ Denotes significance difference at $\mathrm{p} \leq 0.01$, respectively, ns, non-significant difference.

In their study to determine the adaptability of sunflower genotypes grown in different regions, Khan et al. (2008) observed that the results obtained from the Peshawar region were better than those obtained from the Mansehra region. As a result, it was stated that the sunflower soil in the Peshawar region is rich in organic matter due to the lack of cultural practices (weed control) because of the heavy rainfall in the Mansehra region. Previously reported average table diameters of the genotypes grown at different locations are 16.6-22.7 cm
(Y1lmaz and Emiroglu, 1995), 18.3-26.7 cm (Y1lmaz and Bayraktar, 1996) and 13.64-16.29 cm (Iqbal et al., 2018). The researchers stated that the average table diameter of oil sunflower genotypes should be $22-25 \mathrm{~cm}$ in diameter and that these characteristics may change depending on the genetic structure.

\section{Seed Weight}

The 1000 seed weight values of the sunflower genotypes according to the average between years 
according to the results of variance analysis, according to the statistical year $\mathrm{p}<0.05$, location, genotype, year $\mathrm{x}$ location, year $\mathrm{x}$ genotype, location $\mathrm{x}$ genotype and year $\mathrm{x}$ location $\mathrm{x}$ genotype interaction statistically $\mathrm{p}<0.01$ (Table 4). The highest 1000 seed weight among $L_{1}$ and $L_{2}$ was 77.65 and $70.07 \mathrm{~g}$, respectively, in 2015 and 61.48-71.20 $\mathrm{g}$ in 2016. In the same year, the lowest thousand weights at $\mathrm{L}_{1}$ and $\mathrm{L}_{2}$ were $51.15-53.97 \mathrm{~g}$ and $43.43-53.23 \mathrm{~g}$, respectively. According to the yearly averages, the highest 1000 seed weight of the $\mathrm{G}_{9}$ genotypes (61.39-70.13 g) were obtained from $L_{1}$ and $L_{2}$. The differences in the weights of 1000 seed varied according to the genetic factors of the genotypes as well as seed formation and development, which are affected positively or negatively depending on soil and environmental factors.

Mrdja et al. (2012) showed that sunflower production in terms of the 1000 seed weight differences between regions was $8.69 \%$, and they stated that all the interactions of regional production areas are essential. Khan et al.
(2008), according to the results of their adaptation study on sunflower thousand seed weight of genetic, environmental and climatic factors, have changed depending on the genetic. Ashok et al. (2000) also observed similarly high differences between sunflower genotypes at different locations. Our results have been slightly lower than the results of the researchers. Alem et al. (2016) 1000 seed weight of sunflower genotypes grown in different lotions between 47-68 g, Ozer et al. (2004) 61.87-61.98 g, Canavar et al. (2010) 53.40-69.77 g, Iqbal et al. (2018) found that it is between 56.66-68.66 g. These results are similar to our results.

\section{The Ratio of Dehulled/Hulled Seed Weight}

The ratio of dehulled/hulled seed weight was statistically significant in terms of year, location, genotype, and the year $\mathrm{x}$ location, year $\mathrm{x}$ genotype, genotype $\mathrm{x}$ location, and year $\mathrm{x}$ genotype $\mathrm{x}$ location interactions according to $\mathrm{p}<0.01$ (Table 5).

Table 5. The Ratio of Dehulled/Hulled Seed Weight seed yield averages and variance analysis results of sunflower genotypes grown in different regions

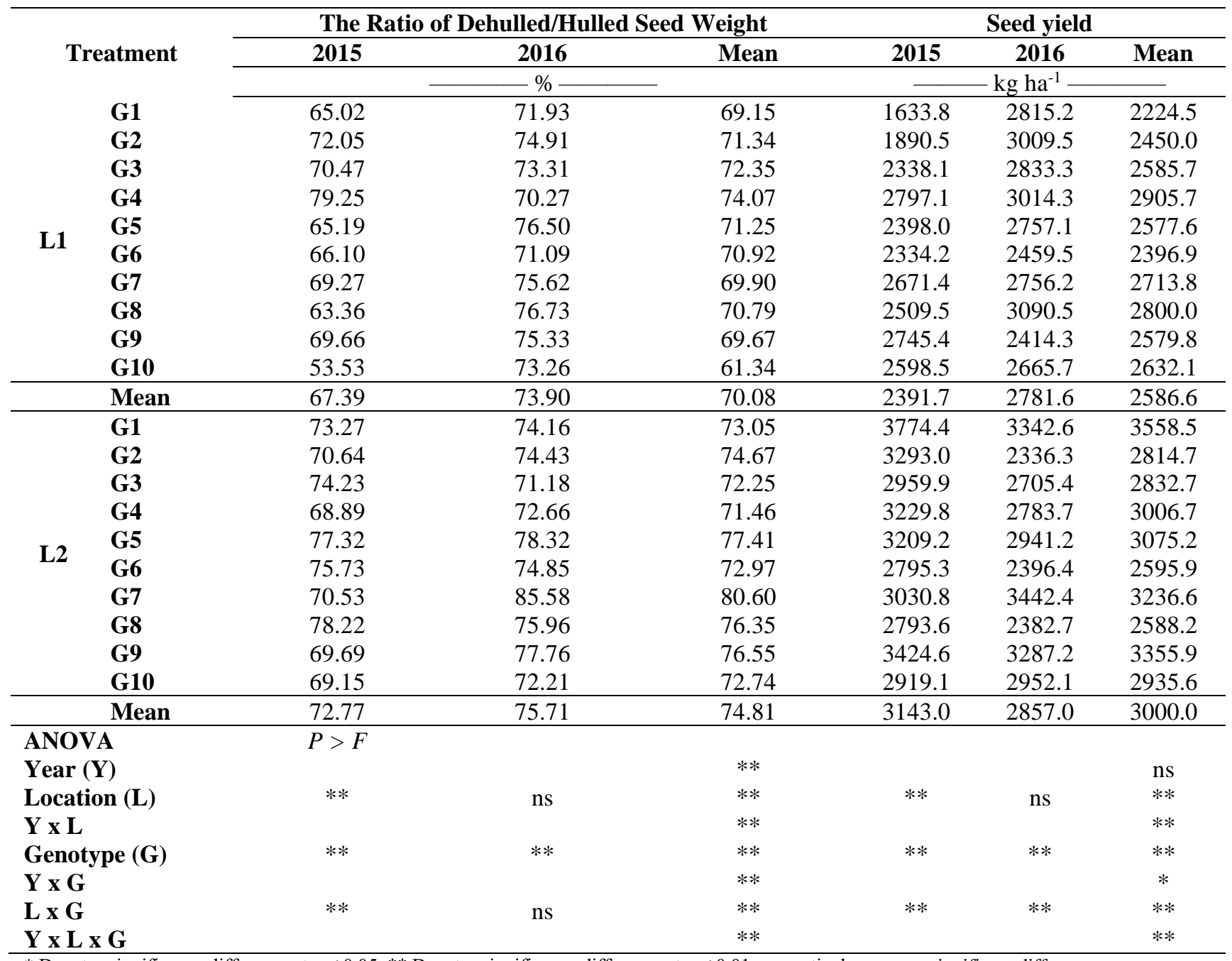

$*$ Denotes significance difference at $\mathrm{p} \leq 0.05 . * *$ Denotes significance difference at $\mathrm{p} \leq 0.01$, respectively, ns, non-significant difference. 
The highest ratio of dehulled/hulled seed weight was obtained from the $\mathrm{G}_{4}$ genotype $(79.25 \%)$ in the first year at $\mathrm{L}_{1}$, while the lowest the ratio of dehulled/hulled seed weight was obtained from the $\mathrm{G}_{10}$ genotype $(53.53 \%)$ in the first year at $\mathrm{L}_{1}$. According to the ratio of dehulled/hulled seed weight across years, the highest ratio of dehulled/hulled seed weight was obtained from the $\mathrm{G}_{7}$ $(80.60 \%)$ genotype. According to the results, the average ratio of dehulled/hulled seed weight at the $\mathrm{L}_{2}$ was higher than that at the $\mathrm{L}_{1}$.

Killi and Tekeli (2016) found that the sunflower genotype yields were 54.65-73.51\% under Kahramanmaras conditions. The result of this study is similar to our study. The ratio of dehulled/hulled seed weight of sunflowers varies depending on environmental, cultural, and climatic conditions (Canavar et al., 2010).

\section{Seed Yield}

In terms of seed yield, the year $\mathrm{x}$ genotype interaction was significant at $p<0.05$, while all other parameters were statistically significant according to $\mathrm{p}<0.01$. The mean and variance analysis results of these parameters are given in Table 5 .

When seed yield, which is one of the most important parameters for oil sunflowers, was examined, the highest seed yield (3143.0 kg ha-1) was obtained from $\mathrm{L}_{2}$ in 2015 . According to the genotypes, the highest seed yield (3774.4 $\mathrm{kg} \mathrm{ha}^{-1}$ ) was obtained from the $\mathrm{G}_{1}$ at $\mathrm{L}_{2}$ and the lowest seed yield (1633.8 $\mathrm{kg} \mathrm{ha}^{-1}$ ) was obtained from the $\mathrm{G}_{1}$ at $\mathrm{L}_{1}$ in 2015. As a result, it was observed that although the $G_{1}$ gave the lowest value in terms of seed yield, it gave the highest average seed yield across all years and locations. This difference can be evaluated as the response of the genotype to climatic factors, environmental factors, and regional cultivation techniques (Kaleem et al., 2011; Onemli, 2012).

Ashok et al. (2000) also observed that there were similarly high differences between sunflower genotypes at different locations. When determining the effect of early sunflower genotypes on yield, Cvejić et al. (2015) found that the highest yield $\left(4028 \mathrm{~kg} \mathrm{ha}^{-1}\right)$ was obtained from the Novi Sad-El region while the lowest yield $\left(2222 \mathrm{~kg} \mathrm{ha}^{-1}\right)$ was obtained from the Novo Miloševo- $\mathrm{E}_{3}$ region. They stated that the differences between locations might vary depending on environmental and climatic factors. Kang (2002) also reported that the change in yield parameters of certain genotypes depended on environmental factors. Marjanović-Jeromela et al. (2011) stated that some genotypes were adapted to specific seasons in terms of seed yield and were highly affected by environmental factors. Iqbal et al. (2018) showed that the seed yield of genotypes ranged from 922.6 to $2187 \mathrm{~kg} \mathrm{ha}^{-1}$. Taran et al. (2013), Pakistan, Balochistan in the highlands of sunflower genotypes grown in the study to determine the adaptability ability; seed yield of sunflower genotypes varied between $1724.9-2128 \mathrm{~kg} \mathrm{ha}^{-1}$. Likewise, Alem et al. (2016) have determined that the seed yield of sunflower genotypes grown in different locations ranged from 951 to $2926 \mathrm{~kg} \mathrm{ha}^{-1}$. While these results were similar to our results, they stated that the sunflower genotypes were sensitive to environmental factors and, therefore, the genotypes varied depending on the differences among locations (Coates, 2009; Ayerza, 2010; Zavalía al., 2011).

\section{Oil content and oil yield}

When evaluating the oil content and oil yield, we observed that year did not affect both properties. However, they were statistically significant in terms of location, genotype, and the year $\mathrm{x}$ location, year $\mathrm{x}$ genotype, genotype $\mathrm{x}$ location, and year $\mathrm{x}$ genotype $\mathrm{x}$ location interactions at $\mathrm{p}<0.01$ (Table 6).

Two critical parameters of the sunflower oil seed used in vegetable oil production and breeding studies are oil content and oil yield. According to our results, the oil contents at $\mathrm{L}_{1}$ and $\mathrm{L}_{2}$ varied from 36.47 to $50.29 \%$ and 36.08 to $47.07 \%$, respectively. The highest oil content $(44.77 \%)$ was obtained from $\mathrm{L}_{1}$ when averaged across years. The highest oil content (respectively 46.59 and $46.27 \%$ ) at $\mathrm{L}_{1}$ and $\mathrm{L}_{2}$ were obtained from the $\mathrm{G}_{7}$.

The amount of oil calculated on the basis of seed yield and oil content per hectare is very important in terms of oil yield obtained. The highest average oil yield (1360.8 $\mathrm{kg} \mathrm{ha}^{-1}$ ) was obtained from $\mathrm{L}_{2}$ in 2015, while the lowest average oil yield (1094.3 $\mathrm{kg} \mathrm{ha}^{-1}$ ) was obtained from $\mathrm{L}_{1}$. The highest oil yield $\left(1535.6 \mathrm{~kg} \mathrm{ha}^{-1}\right)$ was obtained from the $G_{1}$ at $L_{2}$. According to the average of years, the highest oil yield was $1304.6 \mathrm{~kg}$ per hectare. Although the same genotypes were used in different regions, the results clearly show how effective environmental factors are.

Alem et al. (2016) found that the oil content and oil yield of sunflower genotypes grown in different locations were between 28.18-33.50\% and 307-959 $\mathrm{kg} \mathrm{h}^{-1}$, respectively. These results were lower than our results. Since yield, genotype, environmental conditions, climatic factors, and cultivation techniques significantly affect sunflowers, it is important to select the genotypes that are genetically resistant to diseases, compatible with environmental conditions, and show high oil quality (Guvercin et al., 2002). Ashok et al. (2000) also observed that there were similarly high differences between sunflower genotypes at different locations. Miller and Vick (1999), Sobrino et al. (2003), Zheljazkov et al. (2008) and Cvejić et al. (2015) reported that there are significant differences between genotypes grown in different locations in terms of oil content and oil yield depending on climatic and environmental factors. 
Table 6. Oil content, oil yield averages and variance analysis results of sunflower genotypes grown in different regions

\begin{tabular}{|c|c|c|c|c|c|c|c|}
\hline \multirow{3}{*}{\multicolumn{2}{|c|}{ Treatment }} & \multicolumn{3}{|c|}{ Oil content } & \multicolumn{3}{|c|}{ Oil yield } \\
\hline & & 2015 & 2016 & Mean & 2015 & 2016 & Mean \\
\hline & & \multicolumn{3}{|c|}{$\%$} & \multicolumn{3}{|c|}{$\mathrm{kg} \mathrm{ha}^{-1}$} \\
\hline \multirow{11}{*}{ L1 } & G1 & 47.83 & 45.03 & 46.43 & 781.7 & 1267.7 & 1024.7 \\
\hline & G2 & 36.47 & 47.70 & 42.09 & 689.5 & 1435.7 & 1062.6 \\
\hline & G3 & 45.35 & 45.33 & 45.34 & 1060.4 & 1284.6 & 1172.5 \\
\hline & G4 & 44.73 & 42.58 & 43.66 & 1251.2 & 1283.6 & 1267.4 \\
\hline & G5 & 46.69 & 45.01 & 45.85 & 1119.4 & 1241.4 & 1180.4 \\
\hline & G6 & 46.84 & 40.40 & 43.62 & 1093.2 & 993.7 & 1043.5 \\
\hline & G7 & 50.29 & 42.89 & 46.59 & 1343.7 & 1181.8 & 1262.8 \\
\hline & G8 & 46.44 & 41.22 & 43.83 & 1164.9 & 1274.1 & 1219.5 \\
\hline & G9 & 46.74 & 44.35 & 45.55 & 1283.1 & 1070.7 & 1176.9 \\
\hline & G10 & 44.47 & 45.03 & 44.75 & 1155.5 & 1200.4 & 1178.0 \\
\hline & Mean & 45.59 & 43.95 & 44.77 & 1094.3 & 1223.4 & 1158.8 \\
\hline \multirow{11}{*}{$\mathbf{L 2}$} & G1 & 44.05 & 42.18 & 43.11 & 1664.1 & 1407.0 & 1535.6 \\
\hline & G2 & 36.08 & 44.35 & 40.21 & 1187.7 & 1036.5 & 1112.1 \\
\hline & G3 & 44.06 & 40.56 & 42.31 & 1312.3 & 1096.9 & 1204.6 \\
\hline & G4 & 45.98 & 41.51 & 43.75 & 1485.2 & 1155.7 & 1320.5 \\
\hline & G5 & 44.71 & 46.90 & 45.80 & 1432.8 & 1379.9 & 1406.3 \\
\hline & G6 & 44.68 & 44.02 & 44.35 & 1252.4 & 1056.9 & 1154.7 \\
\hline & G7 & 47.07 & 45.46 & 46.27 & 1426.0 & 1562.1 & 1494.1 \\
\hline & G8 & 42.68 & 45.32 & 44.00 & 1191.4 & 1077.9 & 1134.7 \\
\hline & G9 & 43.00 & 45.86 & 44.43 & 1474.2 & 1501.6 & 1487.9 \\
\hline & G10 & 40.38 & 40.99 & 40.69 & 1181.9 & 1208.0 & 1195.0 \\
\hline & Mean & 43.27 & 43.72 & 43.49 & 1360.8 & 1248.3 & 1304.6 \\
\hline \multirow{2}{*}{\multicolumn{2}{|c|}{$\begin{array}{l}\text { ANOVA } \\
\text { Year (Y) }\end{array}$}} & $P>F$ & & & & & \\
\hline & & & & ns & & & ns \\
\hline \multicolumn{2}{|c|}{ Location (L) } & $* *$ & ns & $* *$ & $* *$ & ns & $* *$ \\
\hline \multicolumn{2}{|c|}{$\mathbf{Y} \times \mathbf{L}$} & & & $* *$ & & & $* *$ \\
\hline \multicolumn{2}{|c|}{ Genotype (G) } & $* *$ & $* *$ & $* *$ & $* *$ & $* *$ & $* *$ \\
\hline \multicolumn{2}{|c|}{$Y \times G$} & & & $* *$ & & & $* *$ \\
\hline \multicolumn{2}{|c|}{$\mathbf{L} \times \mathbf{G}$} & ns & $* *$ & $* *$ & $* *$ & $* *$ & $* *$ \\
\hline \multicolumn{2}{|c|}{$Y \times L \times G$} & & & $* *$ & & & $* *$ \\
\hline
\end{tabular}

*Denotes significance difference at $\mathrm{p} \leq 0.05$.** Denotes significance difference at $\mathrm{p} \leq 0.01$, respectively, ns, non-significant difference.

\section{CONCLUSION}

When evaluating the yields and yield components of different sunflower genotypes grown under Samsun $\left(\mathrm{L}_{1}\right)$ and Erzurum $\left(\mathrm{L}_{2}\right)$ ecological conditions have found that the yield parameters were higher in 2016 than in 2015. When the sunflower genotypes were evaluated in terms of average seed yield and average oil content across years, the highest average seed yield was obtained from the $G_{1}$ grown in the Erzurum, and the highest oil content $\left(\mathrm{G}_{7}\right)$ was obtained from Samsun (Kavak). Across the years, the lowest seed yield was obtained from the $\mathrm{G}_{4}$ grown in the Samsun (Kavak) region, and the lowest average oil yield was obtained from the $\mathrm{G}_{2}$ genotype grown in the Erzurum region. Considering the climatic and environmental factors among years, it is evident that there is a significant difference between seed yield and oil content. In two different locations, the highest seed yield was obtained while the climate (annual average temperature and rainfall were high) and soil properties were pleasent, while the oil content was lowest. This study clearly shows that there is an inverse correlation between seed yield and oil content depending on elevation and climatic factors (such as temperature and precipitation) where high yield does not always mean high quality. This difference indicates the importance of regional sunflower cultivation and the importance of such studies. Oil quality is profoundly affected by the climate, elevation and soil characteristics of the region, and the determination of oil sunflower genotypes suitable for the region will allow for highly efficient cultivation and high-quality products.

\section{LITERATURE CITED}

Adugna, W. and M.T. Labuschagne. 2003. Parametric and nonparametric measures of phenotypic stability in linseed (Linum usitatissimum L.). Euphytica. 129: 211-218.

Alberio, C., N.G. Izquierdo and L.A.N. Aguirrezabal. 2005. Sunflower Crop Physiology and Agronomy. In: Sunflower: chemistry, production, processing, and utilization, ed. Martínez-Force, E., Dunford, N.T. and Salas, J.J., 53-93, Elsevier.

Alem, C., A. Worku, M. Mekonnen, T. Asres, D. Fentie, E. Mihiretu and J. Esmael. 2016. GGE stability analysis of seed yield in sunflower genotypes (Helianthus annuus L.) in western Amhara Region, Ethiopia. International J. Pl. Breed. and Genet. 10: 104-109.

Andrich, G., S. Balzini, A. Zinnai, V. De Vitis, S. Silvestri, F. Venturi and R. Fiorentini. 2001. Supercritical fluid 
extraction in sunflower seed technology. European journal of lipid science and technology. 103(3): 151-157.

Arioglu, H.H. 2007. Growing and breeding of oil plants course book. Publication No: 220. Adana (in Turkish).

Ashok, S., S. Mohamed and S.L. Narayanan. 2000. Combining ability studies in sunflower (Helianthus annuus L.). Crop Research. 20(3): 457-462.

Ayerza, R. 2010. Effects of seed color and growing locations on fatty acid content and composition of two chia (Salvia hispanica L.) genotypes. Journal of the American Oil Chemists Society. 87(10): 1161-1165.

Canavar, O., F. Ellmer and F.M. Chmielewski. 2010. Investigation of yield and yield components of sunflower (Helianthus annuus L.) cultivars in the ecological conditions of Berlin (Germany). Helia. 33(53): 117-130.

Coates, W. 2009. Influence of environment on growing period and yield, protein, oil and $\alpha$-linolenic content of three chia (Salvia hispanica L.) selections. Industrial Crops and Products. 30(2): 321-324.

Cvejić, S., S. Jocić, I. Radeka, M. Jocković, V. Miklič, V. Mladenov and V. Lončarević. 2015. Evaluation of stability in new early-maturing sunflower hybrids. Journal on Processing and Energy in Agriculture. 19(5): 255-258.

Goyne, P.J. and G.L. Hammer. 1982. Phenology of sunflower cultivars. 2nd controlled environment studies of temperature and photoperiod effects. Australian Journal of Agricultural Research 33(2): 251-261.

Guvercin, R.S., M. Tanriverdi and H.A. Yilmaz. 2002. A research on yield and yield components of some sunflower varieties that can be grown in Harran Plain. Harran University Journal of Agriculture Faculty 6(3-4): 57-64.

Habibullah, H., S.S. Mehi, M.A. Anjum and R. Ahmad. 2007. Genetic association and path analysis for oil yield in sunflower (Helianthus annuus L.). Int. J. Agric. Biol. 9(2): 359-361.

Iqbal, Q., A. Safdar, M.N. Tahir, O. Shafique, B.A. Khan, A. Ijaz and I. Khan. 2018. Assessment of different exotic sunflower hybrids for their agro-ecological adaptability. Pakistan Journal of Agricultural Research 31(2): 122-132.

Khan, H., H. Ur-Rahman, H. Ahmad, H. Aliinamullah and M. Alam. 2008. Magnitude of combining ability of sunflower genotypes in different environments. Pakistan Journal of Botany 40(1): 151-160.

Kaleem, S., F.U. Hassan M. Ahmad, I. Mahmood, A. Wasaya, M.A. Randhawa and P. Khaliq. 2011. Effect of growing degree days on autumn planted sunflower. African Journal of Biotechnology 10(44): 8840-8846.

Kang, M.S. 2002. Genotype-environment interaction: Progress and prospects. In: M.S. Kang (Ed.), Quantitative genetics, genomics and plant breeding, $\mathrm{CAB}$ International: Wallingford: England.

Killi, F. and F. Tekeli. 2016. Seed yield and some yield components of sunflower (Helianthus annuus L.) genotypes in Kahramanmaras (Turkey) Conditions. Journal of Scientific and Engineering Research 3(4): 346-349.

Klute A. and R.C. Dinauer. 1986. Physical and mineralogical methods. Planning. 8: 79.

Marjanović-Jeromela, A., N. Nagl, J. Gvozdanović-Varga, N. Hristov, A. Kondić-Š́pika and M.V.R. Marinković. 2011. Genotype by environment interaction for seed yield per plant in rapeseed using AMMI model. Pesquisa Agropecuária Brasileira. 46(2): 174-181.
Miller, J. F. and B.A. Vick. 1999. Inheritance of reduced stearic and palmitic acid content in sunflower seed oil. Crop Science. 39(2): 364-367.

Mrdja, J., J. Crnobarac, V. Radić and V. Miklič. 2012. Sunflower seed quality and yield in relation to environmental conditions of production region. Helia. 35(57): 123-134

Mostafa, S.H.A. and F. Ashmawy. 1998. Performance and yield stability of some flax genotypes. Ann. Agric. Sci. 43: 403417.

Olsen, S.R. and L.E. Sommers. 1982. Phosphorus. In: Methods of soil analysis. Part 2 (Chemical and Microbiological Properties Second Edition), ed. Page, A.L., Miller, R.H. and Keeney, D.R., 403-427, Soil Science Society of America, Inc. Publisher Madison, Wisconsin USA.

Onemli, F. 2012. Impact of climate changes and correlations on oil fatty acids in sunflower. Pakistan Journal of Agricultural Sciences 49: 455-458.

Ozer, H., T. Polat and E. Ozturk. 2004. Response of irrigated sunflower (Helianthus annuus L.) hybrids to nitrogen fertilization: growth, yield and yield components. Plant Soil and Environment 50(5): 205-211.

Page A., R. Miller and D. Keeney. 1982. Methods of soil analysis. Part 2 (Chemical and Microbiological Properties Second Edition). Soil Science Society of America, Inc. Publisher Madison, Wisconsin USA.

Rhoades, J.D. 1982. Cation Exchange Capacity. In: Methods of soil analysis. Part 2 (Chemical and Microbiological Properties Second Edition), ed. Page, A.L., Miller, R.H. and Keeney, D.R., 403-427, Soil Science Society of America, Inc. Publisher Madison, Wisconsin USA.

Schneiter, A.A. and J.F. Miller. 1981. Description of sunflower growth stages 1. Crop Science. 21(6): 901-903.

Sobrino, E., A.M. Tarquis. and M.C. Díaz. 2003. Modeling the oleic acid content in sunflower oil. Agronomy Journal 95(2): 329-334.

Taran, S.A., D.M. Baloch, N.U. Khan, J.E.H.A.N. Bakht, S.H. Ghaloo, N. Shahwani and M. S. Kakar. 2013. Earliness and yield performance of sunflower hybrids in uplands of Balochistan, Pakistan. Pak. J. Bot. 45(4): 1397-1402.

Tozlu, E., T. Dizikisa, A.M. Kumlay, M. Okcu, M. Pehluvan and C. Kaya. 2008. Determination of Agronomic Performance of Some Oilseed Sunflower (Helianthus annuus L.) Hybrids Grown in Erzurum-Pasinler Ecological Conditions. Journal of Agricultural Sciences 14 (4): 359-364.

Yilmaz, H.A. and S.E. Emiroglu. 1995. Hybrid Sunflower (Helianthus annus L.) Breeding Resistance to Orobans, Yield Components and Research on Some Chemical Characters. Tr.J. of Agriculturre and Forestry. 19: 397-406.

Yilmaz, H.A. and N. Bayraktar. 1996. Determination of yield and yield components of 12 sunflower (Helianthus annuus L.) species in two different locations. Journal of Agricultural Sciences 2 (3): 63-69.

Zavalía, R.L., M.G. Alcocer, F.J. Fuentes, W.A. Rodríguez, M. Morandini and M.R. Devani. 2011. Desarrollo del cultivo de chía en Tucumán, Republica Agentina. Revista Avance Agroindustrial. 32(4): 27-30.

Zheljazkov, V.D., B.A. Vick, M.W. Ebelhar, N. Buehring, B.S. Baldwin, T. Astatkie and J.F. Miller. 2008. Yield, oil content, and composition of sunflower grown at multiple locations in Mississippi. Agronomy Journal. 100(3): 635642. 